\title{
Law, Liberty and the Rule of Law (in a Constitutional Democracy)
}

Imer Flores

Georgetown Law Center, imerbflores@law.georgetown.edu

This paper can be downloaded free of charge from: https://scholarship.law.georgetown.edu/facpub/1115

http://ssrn.com/abstract=2156455

Imer Flores, Law, Liberty and the Rule of Law (in a Constitutional Democracy), in LAW, LIBERTY, AND THE RULE OF LAW 77-101 (Imer B. Flores \& Kenneth E. Himma eds., Springer Netherlands 2013)

This open-access article is brought to you by the Georgetown Law Library. Posted with permission of the author. Follow this and additional works at: https://scholarship.law.georgetown.edu/facpub

Part of the Constitutional Law Commons, Jurisprudence Commons, Legislation Commons, and the Rule of Law Commons 


\title{
Chapter 6 \\ Law, Liberty and the Rule of Law (in a Constitutional Democracy)
}

\author{
Imer B. Flores
}

\begin{abstract}
Tse-Kung asked, saying "Is there one word which may serve as a rule of practice for all one's life?"

K'ung-fi-tzu said: "Is not reciprocity (i.e. 'shu') such a word?" What you do not want done to yourself, do not do to others."
\end{abstract}

Confucius (2002, XV, 23, 225-226).

\subsection{Introduction}

Taking the "rule of law" seriously implies readdressing and reassessing the claims that relate it to law and liberty, in general, and to a constitutional democracy, in particular. My argument is five-fold and has an addendum which intends to bridge the gap between Eastern and Western civilizations, on behalf of both "global harmony and the rule of law" and is dedicated to the memory of Neil MacCormick:

Firstly, we will a la Jeremy Waldron, on the one hand, criticize the conceptions, including the dualist - or weak - and the monist - or strong - theses explaining the relationship between "law" and "State" that equate the "rule of law" to the formal assertion that the "law rules" and even worse reduce it either to the "rule of precedent" or "adjudicative/judicial rule of law" ("judicialism") or to the "rule of statute" or "legislative rule of law" ("legalism"). Both options fail by presupposing that for a complete apprehension of the "rule of law" it is sufficient to be acquainted with the "law" - by notions such as "precedent" or "statute", as well as "adjudication" or

I.B. Flores (₫)

Law School and Legal Research Institute,

National Autonomous University of Mexico (UNAM), Mexico City, Mexico

e-mail: imer@unam.mx

I.B. Flores and K.E. Himma (eds.), Law, Liberty, and the Rule of Law, 
"legislation" - to derive mechanically what the "rule of law" is. On the other hand, we will also scrutinize the claim suggesting that instead of presupposing that the comprehension of the "law" will lead us into the knowledge of the "rule of law" it is the other way around: it is necessary to have a better - and more substantial conception of the "rule of law" to have a better - and more substantial - perception of the "law".

Secondly, in the hunt for a better - and more substantial - awareness of the "law", we intend to revisit the different notions related to the "rule of law". Although it is true that they are neither equivalent nor unequivocal, they might shed some light into our discussion, from the classical distinction between the "government of/under men" ("passion") and the "government of/under laws" ("reason") in Socrates, Plato and Aristotle, and the principles of "equality before/under law" (identified with the Greek word isonomia), or "freedom before/under law" in Marcus Tullius Cicero and in Edward Coke to the contemporary distinctions between the "adjudicative/ judicial or legislative rule of law" and the "constitutional or institutional rule of law", including the tensions between the ragione di Stato (i.e. reason of State) and the Stato della ragione (i.e. State of reason); the Machtstaat (i.e. State of power/ force) and rechtsstaat (i.e. State of law); derecho de Estado (i.e. law of State) and Estado de derecho (i.e. State of law or even State-law); and, law's empire - the expression popularized by Ronald Dworkin - or even empire of law.

Thirdly, in the pursuit for the embedded principles in a "constitutional rule of law", we pretend to recognize first a la Friedrich August Hayek some of the principles of the "rule of law", by revisiting analytically and critically Cicero's thought: the conception of general rules; the conception that we obey the law in order to be and remain free; and the conception that the judge is a law that speaks/with voice and the law is a speechless/voiceless judge. All of which are still in force more or less in those exact terms, except the last one which has been distorted by Charles Louis de Secondat, baron de La Brède et de Montesquieu, into the characterization of the judge as the bouche du loi, popularized ever since, and repeated among other by John Marshall. In order to reject this depiction, we will revisit not only Cicero and Coke maxims but also Lon L. Fuller's "implicit laws of lawmaking" or "internal morality of law", which includes eight principles: (1) generality; (2) publicity; (3) irretroactivity - or prospectivity; (4) clarity; (5) non-contradictory; (6) possibility; (7) constancy; and (8) congruity; and Norberto Bobbio's "essential" and "non-essential" attributes of a bon législateur. The former are: (1) justice; (2) coherence; (3) rationality; and (4) non-redundancy; and the latter: (5) rigorous; (6) systematic; and (7) exhaustive. Also following Bobbio we will revisit the relationship of the bon législateur to the bon juge - or juge loyal - which is committed to an "intelligent" fidelity to law a la Fuller, and so must apply the five different types of "legal rationality" that are and must be integrated into a "complex legal rationality" comprising (1) linguistic; (2) legal-formal - or systematic; (3) teleological; (4) pragmatic; and (5) ethical. Above all, we will emphasize that the rule of law functions - contrary to Antonin Scalia conception of "the rule of law" as "the law of rules" - as a limit to both law and rule, and as such it is "the law or rule of principles or reasons" and according to "constitutionalism" of "human rights" and "separation of powers". 
Fourthly, we will re-develop the principles related to the "constitutional rule of law" by recalling the existing tensions not only between liberty and other values but also between the two concepts of liberty, i.e. "negative" and "positive". In addition, we will reinforce the priority of the former over the latter, by analyzing the relationship between individual liberty and democratic rule, and by critically assessing the problem of the limits of the "majority rule", i.e. the so-called "tyranny of the majority". For that purpose, we will revise John Stuart Mill's famous On Liberty, which contains the description of such an evil and the prescription of the remedy as well: the priority of individual liberty over all ends of life and the "harm principle" as a justified limitation to liberty. We will also revisit Isaiah Berlin's illustrious "Two Concepts of Liberty" to reinforce the priority of negative liberty over positive one, and hence of individual liberty over democratic rule, identified solely with the majority rule.

Fifthly, since we are critical of the tendency to reduce the "democratic principle" to the "majority principle" and even worse to the "majority rule", i.e. to whatever pleases the majority, we will like to confront two competing conceptions of democracy, in the quest for an authentic, pure or true "democracy". For that purpose, we will begin by remembering its etymology, which means "government of the people": neither many nor few, but all the people. And by contrasting two conceptions: on one side, the majoritarian conception as the government of the many - and even of the few on behalf of the many; and, on the other, the partnership conception as the government of all, both many and few. This distinction can be traced all the way down to Mill's Considerations on Representative Government and has been reintroduced recently in Dworkin's Is Democracy Possible Here? Principles for a New Political Debate, who by embracing the partnership conception has become the champion of democracy.

Finally, I will like to seize the opportunity to explicit a principle firmly entrenched in the "Eastern" comprehension of the world that is also present in the "Western" one but has remained implicit in our description of the "rule of law". The principle "reciprocity" attributed to Confucius is closely related not only to several of the principles integrated to our conception of the "rule of law", such as "isonomy", "generality", "constancy", "harm principle" - as a justified limitation to liberty and limits to "majority rule", but also to the classic one contained in the Greek word 'isotimia' and to the modern "equal concern and respect" advocated among others by Dworkin and Amartya Sen, following John Rawls and his "difference principle".

\section{2 "Rule"+"Law" ₹“"Rule of Law"}

As stated in introductory section 6.1, the dual aim of this part is: On the one hand, to criticize a la Jeremy Waldron (2008) the conceptions, including the dualist - or weak - and the monist - or strong - theses explaining the relationship between 
"law" and "State" that equate the "rule of law" to the formal assertion: "law rules"; and, even worse, that reduce it either to the "rule of precedent" or "adjudicative/ judicial rule of law" ("judicialism"), or to the "rule of statute" or "legislative rule of law" ("legalism"). Both options fail by presupposing that for a complete apprehension of the "rule of law" it is sufficient to be acquainted with the "law" - by notions such as "precedent" or "statute", as well as "adjudication" or "legislation" - to derive mechanically what the "rule of law" is. On the other hand, to scrutinize the claim suggesting that instead of presupposing that the comprehension of the "law" will lead us into the knowledge of the "rule of law" it is the other way around: it is necessary to have a better - and more substantial - conception of the "rule of law" to have a better - and more substantial - perception of the "law".

Anyway, let me start by denouncing a common mistake that most jurists or legal theorists formed under the Staatslehre and "sovereignty of States" doctrines have and share, whether they hold a weak or a strong theses their mistake is the same. On one side, in the dualist or weak thesis, "law" and "State" are interconnected to the extent that the announcements "where there is law there must be a State" and "where there is a State there must be law", which lead to the pronouncements "all law has a State form" or "all State has a law form" are redundant and the statements "law of State" and "State of law" are simply tautological (Austin 1832, 9-33; Hart 1961, 49-76, 1994, 50-78; MacCormick 1999, 9-11, 2007, 2). ${ }^{\prime}$ On the other, in the monist or strong thesis, both "law" and "State" are unum et idem to the extent that "law of State" and "State of law" are pleonasms: "all State is a State of law" and "all law is a law of State" (Kelsen 1945, 181-206, 1967, 279-319, 2002, 97-106).

In Hans Kelsen's own voice (1945, xxxviii):

\begin{abstract}
Austin shares the traditional opinion according to which law and State are two different entities, although he does not go far as most legal theorists who present the State as the creator of the law, as the power and moral authority behind the law, as the god of the world of law. The pure theory of law shows the true meaning of these figurative expressions. It shows that the State as a social order must necessarily be identical with the law or, at least, with a specific, a relatively centralized legal order, that is, the national legal order in contradistinction to the international, highly decentralized, legal order. Just as the pure theory of law eliminates the dualism of law and justice and the dualism of objective and subjective law, so it abolishes the dualism of law and State. By doing so it establishes a theory of the State as an intrinsic part of the theory of law and postulates a unity of national and international law with a legal system comprising all the positive legal orders.
\end{abstract}

In the words of - one of his critics - Edgar Bodenheimer $(1962,101)$ :

A term like "government of laws" is considered devoid of meaning by Kelsen. "Every State is a government of laws", he says. To him, "law and the state" are synonymous concepts. The state is nothing but the sum total of noms ordering compulsion, and it is thus coextensive with the law. "The law, the positive law (not justice) is precisely that compulsive order which is the State."

\footnotetext{
'Vid. v.gr. MacCormick (2007, 2): "Law taken in this sense [i.e. as an institutional normative order] is obviously a central important feature of states as such and, in particular, of constitutionalist states or 'law-states'."
} 
Accordingly, if our criticism is right, we can derive two central ideas for this part of the paper: First, it should be clear that "not all State is and must be necessarily of law" and "not all law is and must be necessarily of State". Consider an authoritarian or totalitarian regime of "State" which is by definition antagonistic to "law" or at least to its principles; and the "law" of a primitive community or society, which has not developed, or at least not yet, the characteristics fixed for a "State", as a "municipal legal system" (Hart 1961, 89-90, 1994, 91-2). Second, it is true that even in the case of identity between "law" and "State" there is still difference regarding the expressions "law of State" or "State of law". The latter corresponds to the German Rechtstaat (i.e. "State of law" or "State-law") ${ }^{2}$ and the former to the Machtstaat (i.e. "State of force/power"); and, correspondingly to the Spanish terms Estado de derecho (i.e. "State of law" or "State-law") and derecho de Estado (i.e. law of State) or even Estado de fuerza/poder (i.e. "State of force/power").

And so, following Waldron, who suggests that the "rule of law" $(R o L)$ is different from both "rule" $(R)$ and "law" $(L)$, and from the aggregation of both $(R+L)$, to the extent that it must not be identified and less reduced to them, we consider that the "State of law" $(S o L)$ is distinct from both "State" $(S)$ and "law" $(L)$, and from the conjunction of both $(S+L)$, to the extent that it also must not be identified and less reduce to them ${ }^{3}$ :

$$
\begin{aligned}
& R o L \neq R \\
& R o L \neq L \\
& R o L \neq R+L
\end{aligned}
$$

Instead, of believing that our knowledge of either $R$ and $L$ is sufficient for our understanding of $R o L$ the result is that it is different to them or at least to the union of both. In a few words, if not all $R$ or $L$ is identical to $R o L$, then for being consider as such both must have some characteristics beyond merely being $R$ and $L$. But which are those characteristics $(x)$ is still an open question looking for answers:

$$
R=R x ? \text { and } L=L x ?
$$

Also, following Waldron, we consider that it is possible to turn the tables in order to invert the implication $(\rightarrow)$ according to which it is enough to analyze $R$ and $L$ for our knowledge of what the RoL is:

$$
R+L \rightarrow R o L
$$

\footnotetext{
${ }^{2}$ Vid. v.gr: MacCormick (2007, 3): "This [i.e. the distinction between politics and public Law] has much to do with sustaining the character of a state as a law-state. ('Law-state' is here used to refer to a state-under-law, or a constitutionalist state, in which the exercise of power is subjected to effective constitutional constraints and the rule of law obtains, it is equivalent to the German term 'Rechtsstaat'.)"

${ }^{3}$ Since we consider that $R o L$ is equivalent to $S o L$, as we will insist in the following part, hereinafter we will refer explicitly to RoL, but mutatis mutando it applies implicitly to SoL.
} 
On the contrary, we argue that it is the other way around to the extent that the $R o L$ is necessary for a better understanding of both $R$ and $L$ :

$$
R o L \rightarrow R+L
$$

Therefore, when our comprehension of RoL appeared to be subordinated to our knowledge both of $R$ and $L$ it results that the analysis of $R o L$ is essential for understanding both $R$ and $L$ :

$$
R o L x \rightarrow R x+L x
$$

In other words, instead of deducting what $R o L$ is from $R$ and $L$ it is possible from the characteristics $(x)$ of $R o L$ to infer those implanted in $R$ and $L$ to the extent that it is necessary to have a better - and more substantial - conception of $R o L$ to have a better - and more substantial - perception of both $R$ and $L$.

\subsection{Rule of Law}

In this part, in the search for a better - and more substantial - awareness of the "law", we intend to revisit the different notions related to the "rule of law". Although it is true that they are neither equivalent nor unequivocal, they might shed some light into our discussion, from the classical distinction between the "government of/under men" ("passion") and the "government of/under laws" ("reason"), including the principles of "equality before/under law" (isonomia) or "freedom before/under law", to the contemporary distinctions between "adjudicative/judicial or legislative rule of law" and "constitutional or institutional rule of law", including the tensions between the ragione diStato (i.e. reason of State) and the Stato della ragione (i.e. State of reason); the Machtstaat (i.e. State of power/force) and Rechtsstaat (i.e. State of law); derecho de Estado (i.e. law of State) and Estado de derecho (i.e. State of law or State-law); and law's empire - or the empire of law.

It is a common place since ancient classical Greek and Roman times to question: what is better a government of/under men or a government of/under law? On this regard, for instance, Aristotle $(1988,75)$ begins by "inquiring whether it is more advantageous to be ruled by the best man or by the best laws." Certainly, he prefers the government of the best laws to regulate abstract and general cases with reason. But he does not rule out completely the government of the best men to resolve concrete and particular cases with passion. ${ }^{4}$ In his own voice (Aristotle 1988, 76):

Hence it is clear that government acting according to written laws is plainly not the best. Yet surely the ruler cannot dispense with the general principle which exists in law; and that is a better ruler which is free from passion than that in which it is innate. Whereas the law is

\footnotetext{
${ }^{4}$ At the end of the day it seems to be a false dilemma: we must be governed both by the best laws (reason) and by the best human beings (passion). It is in the case of an actual or eventual conflict betweer them that the laws and reasons ought to prevail over human beings and passion.
} 
passionless, passion must always sway the heart of man. Yes, it may be replied, but then on the other hand an individual will be better able to deliberate in particular cases.

The best man, then, must legislate, and laws must be passed, but these laws will have no authority when they miss the mark, though in all other cases retaining their authority.

Moreover, in the Nicomachean Ethics, Aristotle clarifies (1999, 77):

For the just belongs to those who have law in their relations. Law belongs to those among whom injustice is possible; for the judicial process is judgment that distinguishes the just from the unjust. Where there is injustice there is also doing justice, though where there is doing injustice there need not also be injustice. And doing injustice is awarding to oneself too many of the things that, considered without qualification, are good, and too few of the things that, considered without qualification, are bad.

That is why we allow only reason, not a human being, to be ruler. For a human being awards himself too many goods and becomes a tyrant; a ruler, however, is a guardian of the just, and hence of the equal and so must not award himself too many goods.

Likewise, in his Politics, he wonders what must happen if law is not enough and it is necessary to be ruled by men, either by one man or by many/all, his answer seems to suggest that the latter is better than the former, because their reason will outmanoeuvre and outsmart his passion (Aristotle 1988, 76):

But when the law cannot determine a point at all, or not well, should the one best man or should all decide? According to our present practice assemblies meet, sit in judgment, deliberate, and decide, and their judgments all relate to individual cases. Now any member of the assembly, taken separately, is certainly inferior to the wise man. But the state is made up of many individuals. And as a feast to which all the guests contribute is better than a banquet furnished by a single man, so a multitude is a better judge of many things than any individual.

Analogously, Cicero - referring to Cato the Elder - insists on the intrinsic advantages of being ruled not by one genius - and his passion - but by many geniuses - and their reason (Cicero 1929, 154-5):

He often said that the form of our government excelled that of all other states because in the latter there had usually been individual law-givers each of whom had given laws and institutions to his own particular commonwealth... Our commonwealth, on the other hand, was the product not of one genius but of many; it was not established within the lifetime of one man but was the work of several men in several generations. For, as Cato said, there had never been a genius great enough to comprehend everything, and all the ability in the world, if concentrated in a single person, could not at one time possess such insight as to anticipate all future needs, without the knowledge conferred by experience and age.

Correspondingly, Sir Edward Coke, Chief Justice of the Court of Common Pleas, first, and of the King's Bench, later, in times of James I, arrives to a similar conclusion ingrained in his notorious conception of law as an "artificial reason". To cut a long story short, in 1607, he objected the absolute sovereignty of the monarch and his decision to exercise the privilege of deciding personally a case at law, because it requires an artificial logic, in which he is not skilled; and, stated the supremacy of the "common law". Ever since, the report on the Prohibitions del Roy has become an icon for the modern notions of "rule of law" and an "independent judiciary", by including a portrait of the exchange with James I by Coke himself $(1607,481)$ :

A controversy of Land between parties was heard by the King, and sentence given, which was repealed for this, that it did belong to the Common Law: Then the King said, that he 
thought the Law was founded upon reason, and that he and others had reason, as well as Judges: To which it was answered by me, that true it was, that God had endowed his Majesty with excellent Science, and great endowments of nature; but his Majesty was not learned in the Lawes of his Realm of England, and causes which concern the life, or inheritance, or goods, or fortunes of his Subjects; they are not to be decided by naturall reason but by the artificiall reason and judgment of Law, which Law is an act which requires long study and experience, before that a man can attain to the cognizance of it; And that the Law was the Golden metwand and measure to try the Causes of the Subjects; and which protected his Majesty in safety and peace: With which the King was greatly offended, and said, that then he should be under the Law, which was Treason to affirm, as he said; To which I said, that Bracton saith, Quod Rex non debet esse sub homine, sed sub Deo et Lege (i.e. The King ought not to be under any man, but under God and the Law).

Actually, one year later, Coke in the Calvin's Case, or the Case of the Postnati (i.e. those born after the accession of James VI of Scotland to the throne of England as James I) insisted (Coke 1608, 173):

Hesterni enim sumus et ignoramus, et vita nostra sicut umbra super terram: for we are but of yesterday, (and therefore had a need of the wisdom of those that were before us) and had been ignorant (if we had not received light and knowledge from our forefathers) and our daies upon the earth are but as a shadow, in respect of the old ancient days and times past, wherein the Laws have been by the wisdom of the most excellent men, in many successions of ages, by long and continual experience (the trial of right and truth) fined and refined, which no one man (being of so short a time) albeit he had in his head the wisdom of all the men in the world, in any one age could ever have effected or attained unto. And therefore it is optima regula, qua nulla est verior aut firmior in jure, Neminen oportet esse sapientiorem legibus: no man ought to take upon him to be wiser than the Laws.

In a few words, the idea of the rule of law as the "government of/under laws" implies that everyone, including the monarch or sovereign, must be under the law. And so, the Elizabethans borrowed from the Greeks the word isonomia meaning "equality of laws to all manner of persons": i.e. governed and governors, poor and rich (and, nowadays, in a constitutional democracy applicable to... believers and non-believers, foreigners and nationals, heterosexuals and homosexuals, men and women, and so forth). They actually readapted it into the English form "isonomy" to describe a state of "equal laws for all and responsibility of the magistrates" and continued in use during the seventeenth century until "equality before the law", "government of law", and "rule of law" gradually displaced it (Hayek 1960, 164).

In short, the rule of law has been identified with the notion that the law rules nomos basileus for the Greeks and lex rex for the Romans - but implies that it must rule not only equally to all who are before/under it, authorities and officials included, but also through reason not passion. Therefore, the ideal of the rule of law accepts the Stato della ragione (i.e. State of reason) with objective constraints and rejects the ragione diStato (i.e. reason of State) without such restraints, including the possibility of reconciling both as Carlo $\mathrm{V}$ once suggested. In the same way, the rule of law concurs with the principles of a Rechtsstaat (i.e. State of law) with effective constraints and conflicts with those of a Machtstaat (i.e. State of power/force) without restraints or not effective. Similarly, although the rule of law includes the stare decisis doctrine it cannot be reduced to the "rule of precedent" or "adjudicative/ judicial rule of law" ("judicialism"); and, analogously, even though the legislative 
decisions are binding it neither can be reduced to the "rule of statute" or "legislative rule of law" ("legalism"). Both options fail by presupposing that for a complete apprehension of the "rule of law" it is sufficient to be acquainted with "law" - by notions such as "precedent" or "statute", as well as "adjudication" or "legislation" to derive mechanically what the "rule of law" is.

Finally, the rule of law as law's empire - or empire of law - incorporates the notion not of a mere recognition of law by the use of a "precedent" or a "statute" in an "adjudicative/judicial or legislative rule of law" but of a true recognition of law by way of its principles, including "coherence" and "integrity", in what we can label as a "constitutional rule of law" (Dworkin 1986). This model integrates the community's constitutional morality into law by using a constructive-interpretative approach "something like" John Rawls' "reflective equilibrium" (1971, 20-1, 48-51) - or H.L.A. Hart's "critical reflective attitude" (1961, 56, 1994, 57) as pointed out by Wilfrid J. Waluchow, among others (Waluchow 2007; Flores 2002, 155-6, 2008, 285-305, 2009a, 37-74).

\subsection{Principles of the Rule of Law}

In this part, we intend to recognize a la Friedrich A. Hayek some of the principles of the "constitutional rule of law", starting like him by remembering Cicero's conceptions, as well as other principles related to the "rule of law", but which are applicable to all, including the authorities and officials. Since the legislator and the adjudicator must observe these principles which establish limits to their respective activities or functions, we will continue by revisiting Lon L. Fuller's "implicit laws of lawmaking" and Norberto Bobbio's "essential and non-essential attributes of the bon législateur", including according to "constitutionalism" the respect for human rights and separation of powers.

It is worth mentioning that Hayek attributes to Cicero the most effective formulations of freedom under the law $(1960,166-7,462)$ :

1. The conception of general rules - leges legum;

2. The conception of obedience to law in order to be and remain free-omnes legum servi summus ut liberi esse possimus; and

3. The conception of the judge as a law that speaks/with voice and of the law as a speechless/voiceless judge - Magistratum legem esse loquentem, legem autem mutum magistratum.

These three maxims are still in force nowadays, after being received and repeated by many authors, among others, by Montesquieu, in his De l'espirit des lois, where he following Cicero not only insisted in the importance of general rules but also redefined liberty and the obedience to civil laws, in the following terms (Hayek 1960, 462):

Liberty consists principally in not being forced to do a thing where the laws do not oblige: people are in this state only as they are governed by civil laws; and because they live under those civil laws they are free. 
Moreover, Montesquieu misinterpreted Cicero's adagio Magistratum legem esse loquentem, legem autem mutum magistratum and reduced the judges to the bouche du loi (Hayek 1960, 462):

The national judges are no more that the mouth that pronounces the word of the law, mere passive beings, incapable of moderating either its force or rigor.

Keep in mind that by this time Coke had already sentenced in the Calvin's Case: Judex est lex loquens (i.e. A judge is a law that speaks) $(1608,174)$. Notwithstanding, John Marshall in Osborn v. Bank of United States repeated Montesquieu's characterization of judges as "the mere mouthpieces of the law" and "capable of willing nothing" (1824, 866).

It is clearly not the same to conceive the judges limited to be the mouth/voice of the law instead of freed to be the law with mouth/voice. The first characterization is reinforced by a very limited understanding of the separation of powers doctrine not only by assuming the existence of an unavoidable conflict between the legislative and the judiciary but also by presuming that such conflict must be solved indefectibly by subordinating the adjudicator to the legislator, due to the arguably democratic, elected and representative nature of the latter and non-democratic, non-elected and non-representative of the former (Flores 2004, 146-54, 2005, 26-52, 2007, $247-66,2008,285-305,2009 \mathrm{a}, 37-74,2009 \mathrm{~b}, 91-110)$. However, the second conception requires a much better understanding of the separation of powers doctrine by promoting collaboration, complementation and coordination between them instead of being necessarily in competition and conflict. Let me bring to mind Waluchow's words $(2007,269-70)$ :

\footnotetext{
Seen in this light, judges and legislators need not to be seen to be in competition with each other over who has more courage or the better moral vision. On the contrary, they can each been seen to contribute, in their own unique ways, from their own unique perspectives, and within their unique contexts of decision, to the achievement of a morally sensitive and enlightened rule of law... judicial review sets the stage for a "dialogue" between the courts and the legislature... [and] is best viewed not as an imposition that thwarts the democratic will but as one stage in the democratic process.
}

In addition to the three principles of the rule of law attributed to Cicero, there are several other principles worth noting:

4. The conception of equality before the law, which implies:

(4a) Isonomy as an equal application to all; and

(4b) The principle "like cases must be treated alike" as embodied in ubi eadem ratio ibi eadem iuris disposition maxim;

5. The conception of a duty to obey the law, including authorities and officials;

6. The conception of legal certainty or security, which recalls principles such as nulla poena sine lege and nullum crimen sine lege;

7. The conception prohibiting the creation of ad hoc tribunals and retroactive legislation or ex post facto; and

8. The conception of a due process of law, which includes principles such as audi alteram partem, i.e. "let no one be a judge in its own cause" and enforcing the 
analogous "let no one be a legislator in its own cause", as recognized, for instance, in the XXVII Amendment of the United States Constitution: "No law, varying the compensation for the services of the Senators and Representatives, shall take effect, until an election of Representatives shall have intervened."

Since the principles of the "rule of law" are applicable to all, including the authorities and officials, the legislator and the adjudicator must observe these principles which establish limits to their respective activities or functions. The "rule of law" means that the authorities and officials, including not only adjudicators but also legislators, are subjected to the law and do have limits, as both Fuller and Bobbio had pointed out.

On the one hand, in the 60's, Fuller made explicit the "implicit laws of lawmaking", which he identified with the "internal morality of law", and included among them $(1968,91-110,1969,39)$ :

1. Generality: laws must be general in their creation and application;

2. Publicity: laws must be public in order to be known and observed;

3. Irretroactivity - or prospectivity: laws must not be retroactive but prospective or at least not abusive of retroactive legislation;

4. Clarity: laws must be clear and precise to be understood and followed;

5. Non-contradictory: laws must not command at the same time a permission and a prohibition;

6. Possibility: laws must not demand something impossible or have a mere symbolic effect;

7. Constancy: laws must be applied equally to all cases at hand; and

8. Congruity: laws must be enforced according to its purpose as a means to an end.

On the other hand, in the early 70's, Bobbio distinguished not only between essential and non-essential attributes of bon législateur, but also between two ideals in opposition (1971, 243-9). On one side, he stipulated that "essential attributes" are those necessary prohibitions that the legislator cannot violate, without exceptions (as imperatives); and, "non-essential attributes" are those contingent - not necessary - that may under certain conditions institute prohibitions to the legislator with exceptions (as directives). Therefore, he established that the former - essential attributes -included the following:

1. Justice: equal treatment to that alike and different treatment to those unlike;

2. Coherence: no (logical) contradictions;

3. Rationality: in the formal-logical or intrinsic sense of zweckrationalität - a la Max Weber; and

4. Non-redundancy: no repetition or unnecessary reiteration.

Whereas, the latter - non-essential attributes - comprise the subsequent:

5. Rigorous: scrupulous in the process of law-making;

6. Systematic: methodical in the order of exposition; and

7. Exhaustive: completeness in the determination of specific cases.

As a consequence, he assumes a necessary just, coherent, rational, and non-redundant legislator, and presumes a contingent rigorous, systematic and exhaustive legislator. 
On the other, he stated as a general rule the ideal of the bon législateur and the juge loyal; and, as the exception the ideal of the bon législateur complemented by the bon juge, in the sense of the well-known bon juge Paul Magnaud. The question is whether the ideals of a juge loyal and a bon juge are compatible or incompatible? In my opinion, a good judge - or adjudicator - is and must be a loyal judge - or adjudicator. Clearly the problem is: loyal to what? (Flores 2004, 149-52, 2005, 38-47.)

On this regard, let me call attention to Fuller's conception of "fidelity to law" and the distinction between "intelligent" and "non-intelligent" fidelities, as he recognized, first, in his celebrated "The Case of the Speluncean Explorers" through an imaginary justice Foster, who embodies his own thought (1999, 1854-9); and, repeated, later, in his renowned "Positivism and Fidelity to Law - A Reply to Professor Hart" (Fuller 1958, 630-72; Hart 1958, 593-629). In most cases a linguistic or literal approach is enough to guarantee the fidelity to law or at least to the words in which law is drafted, but in some cases it will not be sufficient and even non-intelligent, and consequently a different approach is required, i.e. a functional one, to have an intelligent fidelity to law, by asking which is the end, interest or purpose of the law itself in the case at hand (Fuller 1999, 1958): "The truth is that the exception... cannot be reconciled with the words of the statute, but only with its purpose."

We have following critically Manuel Atienza (1989a, 50-1, 1989b, 385-93, 1990, $39-40,1997,27-40$ ) advocated elsewhere for a "complex legal rationality", which is the same in adjudication as in legislation and comprises five different types that are and must be integrated into one (Flores 2005, 35-8, 2007, 264-6, 2009b, 108-9):

1. Linguistic rationality: laws must be clear and precise to avoid the problems of ambiguity and vagueness $(R I)$;

2. Legal-formal - or systematic - rationality: laws must be not only valid - and as such general, abstract, impersonal and permanent - but also coherent, nonredundant, non-contradictory, prospective or non-retroactive, and publicized to avoid problems of antinomies, redundancies and gaps, while promoting the completeness of law as a system $(R 2)$;

3. Teleological rationality: laws must be efficacious in serving as a means to a end and cannot establish something impossible or merely symbolic (R3);

4. Pragmatic rationality: laws must not only be efficacious, but also socially effective and economically efficient in the case of conflict (R4); and

5. Ethical rationality: laws must be just or fair and as a result can neither admit an injustice or the violation of basic as a principles and rights $(R 5){ }^{5}$

\footnotetext{
It is worth pointing out that we agree with Atienza that the (good) legislator must begin by using clear and precise language to avoid problems related to ambiguities and vagueness $(R I)$ and must carry on by inquiring about the coherency and completeness of the legal system to avoid contradictions and gaps $(R 2)$. However, we are at variance with him in the order of the pragmatic and teleological rationalities, and hence, have inverted their places. Our explanation is simple: the legislator must continue by drafting at least one end $(R 3)$ into law, but it may be the case of establishing more than two ends - or sets of interests, purposes or values $-(R 4)$ and not the other way around. Finally, the legislator must guarantee an overall justified principle embedded into the law or at least not violated by it $(R 5)$.
} 
Hence, a (good) legislator - and a (good) adjudicator - knows and must know: the intricacies of our language $(R I)$; the details of our existing legal system - its past, present and future $(R 2)$; the minutiae of our scheme of ends, interests, purposes and values (R3); the ins and outs of their possible consequences and effects $(R 4)$; and, the niceties of every single principle of justice (R5). And, similarly, integrate these five different types of legal rationality into one "complex legal rationality".

In sum, the targeted conception deeply rooted in "legalism" considers that the adjudicator is and must be loyal to the legislator, who created the general, abstract, impersonal and permanent laws to be applied impartially, and that as an exception becomes a bon juge when has to take the place of the bon législateur in order to legislate interstitially (Holmes 1917, 221; Hart 1961, 200, 1994, 205). A complete loyalty - and deference - from the adjudicator to the legislator assumes that the latter is just, coherent, rational-reasonable, and non-redundant. It even presumes that it is also rigorous, systematic and exhaustive in its formulations, and specially presupposes that law-making is a sovereign activity completely free or limitless, with the Latin adage Quod principi placuit vigorem legis habet ("Whatever pleases the prince has the force of law") as the family motto (Waldron 2002, 10).

On the contrary, the alternative conception embodied in "constitutionalism" considers that the adjudicator is and must be loyal to the legislator, as long as the legislator not only does not violate the prohibitions related to Fuller's "implicit laws of lawmaking" and to Bobbio's "essential and non-essential attributes of the bon législateur" but also follows Fuller's "intelligent fidelity to law" by applying a "complex legal rationality" to the problem at hand. Although Justice Antonin Scalia conceives "the Rule of law" as "the law of rules" $(1989,1187)$, the "rule of law" is a limit to both law and rule; and as such it is "the law or rule of principles or reasons" and according to "constitutionalism" of human rights and separation of powers (article 16 of the French Declaration of the Rights of Men and Citizen): "Tout societé dans laquelle la garantie des droits n'est pas assurée, ni la séparation des pouvoirs déterminée, n'a point de constitution."

\subsection{Constitutional Rule of Law}

In this part, we pretend to recall the principles related to the "constitutional rule of law" by recalling the existing tensions not only between liberty and other values but also between the two concepts of liberty, i.e. "negative" and "positive". In addition,

By the same token, the (good) adjudicator must begin by asking about the clarity and precision of the language used $(R l)$; and, only when the language is neither clear nor precise, must carry on by inquiring about the coherency and completeness of the legal system $(R 2)$. Analogously, only when the language and legal system appear to be incoherent or incomplete, the adjudicator must go on to request an end $(R 3)$, as in the case when there are more than two ends - or sets of interests, purposes or values - equally available, by appealing to the better one $(R 4)$. Finally, only when their consequences and effects are illegitimate, the adjudicator must strive to secure an overall legitimate principle ( $R 5)$. 
we will reinforce the priority of the former over the latter, by analyzing the relationship between individual liberty and democratic rule, and by critically assessing the problem of the limits of the "majority rule".

As we have seen the $R o L$ can neither be equated with $R$ or $L$ nor identified with $R+L$ and much less reduced merely to the creation of norms according to adjectiveformal procedures by legislators and its "mechanical" or strict application by adjudicators, i.e. a "legislative rule of law" or "legalism", as well as its "gastronomical" or soft application by adjudicators to the extent of accepting an interstitial "judicial" legislation, i.e. a "adjudicative/judicial rule of law" or "judicialism". On the contrary, the rule of law requires the creation and application of norms to be limited not only by adjective-formal procedures but also by substantive-material principles and a balanced application, i.e. a "constitutional rule of law" or "constitutionalism" (Flores 2005, 38-47).

Accordingly, one of the main problems of the rule of law is the tension existing between strict and even rigorous application of the law by evoking the dura lex, sed lex adage, and its non-application by invoking the summum ius, summa injuria aphorism. In few words, whenever the strict application of the law has - or will have - as a consequence an extreme injustice there are good reasons to question - or at least to doubt - whether such application is really what an intelligent fidelity to law and to the rule of law expects and even requires. So, instead of a literal and an uncritical approach to law and to the rule of law embodied in the Latin adagio Fiat iustitia, et pereat mundus (i.e. "Let justice be done, though the world perish"), we need a critical attitude. ${ }^{6}$

Actually, in a constitutional rule of law, respect to both human rights and the separation of powers function as a limit to what can be authoritatively consider as law. The rule of law implies the obligation to guarantee such principles and as a result can neither accept the unconstrained abuse of basic rights nor admit the unchecked exercise of powers $(R 5)$. As John Stuart Mill recalled in the "Introductory Chapter I" to his celebrated On Liberty $(1989,6)$ :

The aim, therefore, of patriots was to set limits to the power which the ruler should be suffered to exercise over the community: and this limitation was what they meant by liberty. It was attempted in two ways. First, by obtaining a recognition of certain immunities, called political liberties or rights, which it was to be regarded as a breach of duty in the ruler to

${ }^{6}$ Although this adage and its twin Fiat iusticia, ruat calum ("Let justice be done, even if heavens falls") have analogous meanings along the lines of " justice must be done at any price or regardless of consequences." Nowadays, the former - popularized by the Emperor Ferdinand I - is used to criticize a legal opinion or practice that wants to preserve maxims in law at any price despite absurd or contradictory consequences, whereas the latter - recognized by William Murray, Lord Mansfield - is used to eulogize the realization of justice despite appearing to be outweighed by a pragmatic or utilitarian consideration: "The constitution does not allow reasons of state to influence our judgments: God forbid it should! We must not regard political consequences; however formidable soever they might be: if rebellion was the certain consequence, we are bound to say "fiat iustitia, ruat calum' (Let justice be done even if the heaven falls)." (Mansfield 1770, 2561-2.) 
infringe, and which, if he did infringe, specific resistance, or general rebellion, was held to be justifiable. A second, and generally a later expedient, was the establishment of constitutional checks, by which the consent of the community, or of a body of some sort, supposed to represent its interests, was made a necessary condition to some of the important acts of the governing power.

Later on, in due time, the rulers became identified with the ruled, by assuming that they were elected by them and are their representatives (Mill 1989, 7): "What was now wanted was, that the rulers should be identified with the people; that their interest and will should be the interest and will of the nation." To the extent that, apparently, there can be no deviation and much less tension between the ruler and the ruled giving rise to the ideals of "self-government" and of "the power of the people over themselves". However, Mill recognized (1989, 7-8):

The 'people' who exercise the power are not always the same people with those over whom it is exercised; and the 'self government' spoken of is not the government of each by himself, but of each by all the rest. The will of the people, moreover, practically means the will of the most numerous or the most active part of the people; the majority, or those who succeed in making themselves accepted as the majority; the people, consequently, may desire to oppress a part of their number; and precautions are as much needed against this as against any other abuse of power.

The "tyranny of the majority" - as any other tyrannical form - operates mainly through the actions and laws of the public authorities, but it may be the case that one part of the society oppresses the other. In Mill's voice (1989, 8-9):

Protection, therefore, against the tyranny of the magistrate is not enough; there needs protection also against the tyranny of the prevailing opinion and feeling; against the tendency of society to impose, by other means than civil penalties, its own ideas and practices as rules of conduct on those who dissent from them; to fetter the development, and, if possible, prevent the formation, of any individuality not in harmony with its ways, and compel all characters to fashion themselves upon the model of its own. There is a limit to the legitimate interference of collective opinion with individual independence: and to find that limit, and maintain it against encroachment, is as indispensable to a good condition of human affairs, as protection against political despotism.

For this reason, it is necessary to check the power not only of formal institutions but also of informal instruments which facilitate the imposition of one conception over the others, by legal and moral means. The majority cannot cancel the possibility of some individuals - a significant minority and even a numerical majority of the society - of freely conceiving and responsibly fulfilling their own plan of life. As Mill clarifies $(1989,13)$ :

The object of this Essay is to assert one very simple principle, as entitled to govern absolutely the dealings of society with the individual in the way of compulsion and control, whether the means used be physical force in the form of legal penalties, or the moral coercion of public opinion. That principle is, that the sole end for which mankind are warranted, individually or collectively, in interfering with the liberty of action of any of their number, is self-protection. That the only purpose for which power can be rightfully exercised over any member of a civilised community, against his will, is to prevent harm to others.

In consequence the only time in which it is possible to interfere with the realization of someone's plan is to avoid harm to others. The so-called "harm principle" 
of Mill constitutes a clear limit to the exercise of liberty, since it must always de exercise with responsibility in order not to harm others and less impede someone else from achieving their own ends in life. In Mill's own words (1989, 16):

No society in which these liberties are not, on the whole, respected, is free, whatever may be its form of government; and none is completely free in which they do not exist absolute and unqualified. The only freedom which deserves the name, is that of pursuing our own good in our own way, so long as we do not attempt to deprive others of theirs, or impede their efforts to obtain it.

At the heart of Mill's doctrine on liberty there is the pursuit of our own plan of life, as long as it does not harm others. Moreover, in a lengthy paragraph, he acknowledges the appropriate region of human liberty and recognizes (1989, 15-6):

It comprises, first, the inward domain of consciousness; demanding liberty of conscience, in the most comprehensive sense; liberty of thought and feeling; absolute freedom of opinion and sentiment on all subjects, practical or speculative, scientific, moral, or theological. The liberty of expressing and publishing opinions may seem to fall under a different principle, since it belongs to that part of the conduct of an individual which concerns other people; but, being almost of as much importance as the liberty of thought itself, and resting I great part on the same reasons, is practically inseparable from it. Secondly, the principle requires liberty of tastes and pursuits; of framing the plan of our life to suit our own character; of doing as we like, subject to such consequences as may follow: without impediment from our fellow-creatures, so long as what we do does not harm them, even though they should think our conduct foolish, perverse, or wrong. Thirdly, from this liberty of each individual, follows the liberty, within the same limits of combination among individuals; freedom to unite for any purpose not involving harm to others: the persons combining being supposed to be of full age, and not forced or deceived.

In this paragraph Mill not only establishes the "harm principle" as a limit to both individual and collective liberty, but also stipulates two priorities: (1) liberty - and its different kinds - over other ends of life; and, (2) individual liberty over collective liberty. To reinforce these priorities, let me bring to attention that it was Henri Benjamin Constant de Rebeque's distinction amid "liberty of the ancients" and "liberty of the moderns" (1820), which captured, first, the conflict that Isaiah Berlin, the champion of pluralism, later, popularized among the "two concepts of liberty", i.e. between "negative" and "positive" liberties (1969, 118-72).

The former is a liberty "from" and entails "absence of interference"; whilst the latter is a liberty "to" and involves "presence in self-government". As a result there are two competing concepts of liberty: one of the ancients or republicans, identified with a liberty to participate in democratic rule, where the collective or political liberty is accentuated and so community and equality are emphasized; and, other of the moderns or liberals, identified with a liberty from interference, where the individual or civil liberty is highlighted and so individuality and liberty are stressed.

Although the two concepts are in competition nothing precludes the possibility of their collaboration. As Berlin acknowledges (1969, 130): "Self-government may, on the whole, provide a better guarantee of the preservation of civil liberties than other régimes, and has been defended as such by libertarians. But there is no necessary connection between individual liberty and democratic rule." Actually, if democratic 
rule can suppress individual liberty, as Berlin points out, for a society to be truly free it is necessary to be governed by two interrelated principles $(1969,165)$ :

[F]irst, that no power, but only rights, can be regarded as absolute, so that all men, whatever power governs them, have an absolute right to refuse to behave inhumanly; and, second, that there are frontiers, not antificially drawn, within which men should be inviolable, these frontiers being defined in terms of rules so long and widely accepted that their observance has entered into the very conception of what it is to be a normal human being, and, therefore, also of what it is to act inhumanly or insanely; rules of which it would be absurd to say, for example, that they could be abrogated by some formal procedure on the part of some court or sovereign body.

Both principles reinforce the primacy of a right - negative liberty - over a power positive liberty - not only to the degree that certain rules cannot be abrogated by formal procedures but also to the extent that certain minimum area of individual liberty must not be violated by democratic rule $(1969,124)$ :

Consequently, it is assumed... that the area of men's free action must be limited by law. But equally it is assumed... that there ought to exist a certain minimum area of personal freedom which must on no account be violated; for it is over-stepped, the individual will find himself in an area too narrow for even the minimum development of his natural faculties which alone makes it possible to pursue, and even to conceive, the various ends which men hold good or right or sacred. It follows that a frontier must be drawn between the area of private life and that of public authority.

Additionally, Berlin's suggestion is summarized in a well-known paragraph $(1969,171)$ :

Pluralism, with the measure of 'negative' liberty that it entails seems to me a truer and more humane ideal than the goals of those who seek in the great disciplined, authoritarian structures the ideal of 'positive' self-mastery by classes, or peoples, or the whole of mankind. It is truer, because it does, at least recognize the fact that human goals are many, not all of them commensurable, and in perpetual rivalry with one another.

Thus, to reinforce the priority of the negative over the positive liberty, in the remainder of this part we will revisit the relationship between individual liberty and democratic nule, by critically assessing the problem of "majority rule". Since the "unanimity" is virtually impossible, the "majority principle" has been adopted as a device that enables the government to rule by facilitating, on one side, the election of our rulers, including our representatives, and the (national) representation as such, and, on the other, the decision-making process, and the governance. However, the "majority principle" does not imply that any election or decision is justified per se. As we have already pointed out, it is not enough to comply with adjective-formal procedures but to abide by substantive-material principles. All in all, the problem is that the "majority rule" is not identical to a "democratic rule". In a democracy it does not suffice to be concerned with the legitimate interests of the majorities since the minorities must also be respected in order for the legislative decisions to represent the common general interest and be truly general in both their creation and application.

Even though it is true that the majority is legitimated to rule it is also true that it represents - and must represent - the minorities, by respecting their legitimate interests. The problem is that the majority principle tends to degenerate into majority rule by creating winners that take it all without sharing the corresponding part with the 
losers that end up with nothing at all. In a nutshell, the majority rule, in which the winner takes it all, makes politics a zero sum game of win-lose (them or us), instead of a win-win situation for all (them and us).

The justification of the majority principle relies on the notion of "virtual representation", i.e. the winners represent all, both those who voted for and against them, and two principles of reciprocity: (1) the majorities are fluid and not fixed beforehand; and (2) the minorities are capable of becoming part of the governing coalition or majority in the future. Moreover, when the majority consistently and constantly excludes the minority and/or systematically and thoroughly rejects its demands, to the extent not only of ignoring their legitimate interests but also of destroying the virtual representation and the principles of reciprocity, by transforming the legitimate "majority principle" into is antithesis: "majority rule" - also known as the "tyranny of the majority" (Guinier 1994, 102-5). In Mill's words (1989, 8): "in political speculations 'the tyranny of the majority' is now generally included among the evils against which society requires to be in guard." In addition, a couple of years later, in 1861, he added in his Considerations on Representative Government (1958, 104):

The injustice and violation of principle are not less flagrant because those who suffer by them are a minority; for there is not equal suffrage where every single individual does not count for as much as any other single individual in the community. But it is not only a minority who suffer. Democracy, thus constituted, does not even attain its ostensible object, that of giving the powers of government in all cases to the numerical majority. It does something very different: it gives them to a majority of the majority, who may be, and often are, but a minority of the whole.

The problem is that, despite the virtual representation and the principles of reciprocity, the majority neither recognizes nor represents the interests of the minority, as Tocqueville emphasized $(1969,253-4)$ :

The majority, being in absolute command both of lawmaking and of the execution of the laws, and equally controlling both rulers and ruled, regards public functionaries as its passive agents and is glad to leave them the trouble of carrying out its plans.

Notwithstanding, when the majority possess all the power and exercises it beyond any proportion it may lose all its legitimacy, as Madison pointed out one of the objectives of establishing a government is to avoid the dominance of any group with particular interests by recognizing $(1961,323)$ : "It is of great importance in a republic not only to guard the society against the oppression of its rulers but to guard one part of the society against the injustice of the other part." And, reiterating (1961, 324):

In a society under the forms of which the stronger faction can readily unite and oppress the weaker, anarchy may as truly be said to reign as in the state of nature, where the weaker individual is not secured against the violence of the stronger...

Actually, Tocqueville insisted that the will of the majority is the essence of the democratic rule $(1969,247)$ :

The moral authority of the majority is partly based on the notion that there is more enlightenment and wisdom in a numerous assembly than in a single man, and the number of the legislators is more important than how they are chosen... 
The moral authority of the majority is also founded on the principle that the interest of the greater number should be preferred to that of those who are the fewer.

However, he warns that the germ of the tyranny is found precisely in the "omnipotence of the majority". On this regard, he affirms $(1969,251)$ : "I will never grant to several that power to do everything which I refuse to a single man." The majority will must be moderated to control the possibilities of becoming a tyranny. Moreover, the use of power is not necessarily good $(1969,256)$ : "This irresistible power is a continuous fact and its good use only an accident."

In a democracy, the "majority rule" is justified prima facie as long as the majority does not exercise all the power and oppress the minority, by not protecting their interests and rights. It is incontestable that the majority is entitled to a majority of seats but not all since some of them belong to the minority and much less to be unconstrained. The legislative body ought to be a micro-cosmos of the constituency, where both majorities and minorities are represented according to their true representativeness without either adulterations or dilutions of any type. The majority principle means that it is not sufficient to represent the majority but all the people, including the minority.

Likewise, Hamilton warned $(1985,101)$ : "Give all the power to the many, they will oppress the few. Give all the power to the few they will oppress the many. Both therefore ought to have power, that each may defend itself against the other." In other words, democracy is more than the government of the majority. In a pure or true democracy the power is neither in the majority nor in the minority but in all the people. As Mill emphasized (1958, 102-3):

The pure idea of democracy, according to its definition, is the government of the whole people by the whole people, equally represented. Democracy as commonly conceived and hitherto practice is the government of the whole people by a mere majority of the people, exclusively represented. The former synonymous with the equality of all citizens; the latter, strangely confounded with it, is a government of privilege, in favor of the numerical majority, who alone posses practically any voice in the State. This is the inevitable consequence of the manner in which the votes are now taken, to the complete disfranchisement of minorities.

\subsection{Constitutional Democracy and the Rule of Law}

In this part, since we have been critical of the tendency to reduce the democratic principle to the majority rule, i.e. to whatever pleases the majority, we will like to confront two competing conceptions of democracy. For that purpose, we will begin by remembering its etymology, which means "the government of the people": neither many nor few, but all. And by contrasting two conceptions: the majoritarian conception as the government of the many - and even of the few on behalf of the many; and, the partnership conception as the government of all, both many and few.

According to its etymology - demos (people) and kratos (government, power or rule) - "democracy" means "government, power or rule of the people". It is prima 
facie a form of government in contraposition to other forms of government. The classical typology includes not only three "pure" forms: (1) "autocracy" (better known as "monarchy") as government of one - i.e. the monarch; (2) "aristocracy" as government of few - i.e. the better ones; and (3) "democracy" as government of all-i.e. the people. But also three "impure" or "corrupt" forms: (1) "tyranny" as government of one - i.e. the tyrant; (2) "oligarchy" as government of few-i.e. the rich; and (3) "demagogy" as government of many (on behalf of all) - i.e. the poor (or the mob).

It is worth to mention that Aristotle considered "democracy" pejoratively, an equivalent to the term "demagogy", as one vicious extreme in contraposition to "oligarchy" as the other vicious extreme, whereas his politeia was the virtuous middle term by comprising the government of both the poor and the rich. Let me explain that dislike him I will reserve "demagogy" for the "impure" or "corrupt" form and "democracy" for the "pure" or "true" one. But I will assume like him that the latter is the government of all the people: not only of both the poor and the rich but also of both the many and the few (or alternatively of both the majority and the minority).

The problem is that for some authors "democracy" seems to be reduced to the government of the many or of the majority in detriment of the few or of the minority, a so-called majoritarian or populist democracy. On the contrary, an authentic or true "democracy" and democratic government must be neither of poor or rich, nor of many or few (nor of majority or minority), but of all: both of poor and rich, both of many and few (both of majority and minority).

So far the notion of "democracy" as a form of government and the typology has served to emphasize the ownership (or partnership) "of" the political or sovereign power, depending on whether it corresponds to one, few, many, or all. Nevertheless, the exercise of this political or sovereign power not only must be done directly and indirectly "by" its owners (or partners) and their - legitimate - representatives, but also must be done "for" them and their benefit, not in their detriment. The three ideas already sketched can be put together into an integral definition, such as the one contained in Abraham Lincoln's maxim (1990, 308) and in the Fifth French Republic's motto: "government of the people, by the people, for the people".

Thus, a pure or true "democracy" must be the government of, by and for all the people: both poor and rich, many and few, men and women, heterosexuals and homosexuals, believers and non-believers... and so on. Hence, "democracy" is "government of all the people, by all the people - directly on their own ("direct democracy") or indirectly through their representatives ("representative democracy") - and for all the people".

However, as stated a couple of paragraphs above, the problem is that there are two competing conceptions of democracy (Dworkin 2006, 2011; Flores 2010). As far as I know the distinction can be traced all the way back to Mill, who almost 150 years ago, in his Considerations on Representative Government, under the epigraph "Of True and False Democracy: Representation of All, and Representation of the Majority Only", indicated that the two different ideas were usually confounded under the name "democracy". On one side, the true idea was the "government of the 
whole people by the whole people equally represented"; and, on the other, the false "the government of the whole people by a mere majority of the people, exclusively represented" (Mill 1958, 102-3).

Nowadays, as Dworkin pointed out the two competing conceptions of democracy not only coexist but also are still in conflict $(2006,131)$ :

The two views of democracy that are in contest are these. According to the majoritarian view, democracy is government by majority will, that is, in accordance with the will of the greatest number of people, expressed in elections with universal or near universal suffrage. There is no guarantee that a majority will decide fairly; its decisions may be unfair to minorities whose interests the majority systematically ignores. If so, then the democracy is unjust but no less democratic for that reason. According to the rival partnership view of democracy, however, democracy means that the people govern themselves each as a full partner in a collective political enterprise so that a majority's decisions are democratic only when certain further conditions are met that protect the status and interests of each citizen as a full partner in that enterprise. On the partnership view, a community that steadily ignores the interests of some minority or other group is just for that reason not democratic even though it elects officials impeccably by majoritarian means. This is only a very sketchy account of the partnership conception, however. If we find the more familiar majoritarian conception unsatisfactory, we shall have to develop the partnership view in more detail.

Actually, as he acknowledges, the United States of America is neither a pure example of the majoritarian conception of democracy nor of the non-majoritarian (or partnership) one. Although the bipartisan system and the majority rule reinforced the former, since the founding fathers limited the power of the majorities in various forms, by including anti-majoritarian devices, such as the filibuster and the judicial review of the constitutionality of the acts of the other (elected) branches of government, it can be said that they also supported the latter (Dworkin 2006, 137 and 135$){ }^{?}$

On one side, a minority of either 34 or 41 (out of the 100 senators) can block the majority of bringing a decision to a final vote, depending on whether it is a substantive or procedural issue. And, on the other, the power of the political majorities is limited by the recognition of individual constitutional rights that the legislative majorities cannot infringe and much less step over.

Aside Dworkin alerts that the degraded state of the public debate endangers the partnership conception of democracy and strengthens the majoritarian one, including viewing the other as an enemy and politics as a war (2006, 132-3):

If we aim to be a partnership democracy... the degraded state of our political argument does count as a serious defect in our democracy because mutual attention and respect are the essence of partnership. We do not treat someone with whom we disagree as a partner - we treat him as an enemy or at best as an obstacle - when we make no effort either to understand the force of his contrary views or to develop our own opinions in a way that makes them responsive to his. The partnership model so described seems unattainable now because it is difficult to see how Americans on rival sides of the supposed culture wars could come to treat each other with that mutual respect and attention.

\footnotetext{
${ }^{7}$ In fact, the existence of the Senate was designed to divide the most dangerous branch of government and to give stability to the government by protecting the minorities against a speedy and unreflected legislative majority in the House of Representatives.
} 


\subsection{Conclusion}

To conclude let me explicit one more principle that intends to bridge the gap between East-West but has remained implicit in our description of the "rule of law". The principle known as "shu", i.e. "reciprocity" is attributed to K'ung-fu-tzu-Westernized as Confucius- and is closely related not only to several of the principles already integrated in our conception of the "rule of law", such as "isonomy", "generality", "constancy", "harm principle" - as a justified limitation to liberty - and limits to "majority rule", but also to the classic one contained in the Greek word 'isotimia' and to the modern "equal concern and respect" - that any society must have and show to its individual members and partners, especially those less advantaged - advocated among others by Dworkin $(1978,223-39,1985,181-204,1986,297-301,1996,26-9,2000,120-34)$ and Amartya Sen (1992, 12-30), following John Rawls and his "difference principle" $(1971,75-83)$.

As you know Confucius had an apparent simple set of moral and political principles, including: (1) to love others; (2) to honor one's parents; (3) to do what is right instead of what is of advantage; (4) to practice "reciprocity", i.e. "don't do to others what you would not want yourself"; (5) to rule by moral example instead of by force and violence; and so forth.

These are very humane principles developed arguably without a hint of the ideals of individual liberty that are the basis of the modern liberal society, but "reciprocity" as a golden rule is compatible not only with the liberal "harm principle" but also with the egalitarian "difference principle". As Rawls claims (1971, 102-3):

[T] he difference principle expresses a conception of reciprocity. It is a principle of mutual benefit. We have seen that, at least when chain connection holds, each representative man can accept the basic structure as designed to advance his interests. The social order can be justified to everyone, and in particular to those who are least favoured; and in that sense it is egalitarian.

Additionally, he contends (Rawls 1971, 105-6):

A further merit of the difference principle is that it provides an interpretation of the principle of fraternity. In comparison with liberty and equality, the idea of fraternity has had a lesser place in democratic theory. It is thought to be less specifically a political concept, not in itself defining any of the democratic rights but conveying instead certain attitudes of mind and forms of conduct without which we would lose sight of the values expressed by these rights... It does seem that the institutions and policies which we most confidently think to be just satisfy its demands, at least in the sense that the inequalities permitted by them contribute to the well-being of the less favoured.

And, finally, concludes (Rawls 1971, 106):

On this interpretation, then, the principle of fraternity is a perfectly feasible standard. Once we accept it we can associate the traditional ideas of liberty, equality, and fraternity with the democratic interpretation of the two principles of justice as follows: liberty corresponds to the first principle, equality to the idea of equality in the first principle together with equality of fair opportunity, and fraternity to the difference principle. In this way we have found a 
place for the conception of fraternity in the democratic interpretation of the two principles, and we see that it imposes a definite requirement on the basic structure of society. The other aspects of fraternity should not be forgotten, but the difference principle expresses its fundamental meaning from the standpoint of social justice.

Anyway, "reciprocity" - in the form not only of "fraternity" but also of "community" or "solidarity" - complements both liberty and equality. Actually, the Declaration of the Rights of Man and of the Citizen of 1789 defined liberty in article 4 as follow: "Liberty consists of being able to do anything that does not harm others: thus, the exercise of the natural rights of every man or woman has no bounds other than those that guarantee other members of society the enjoyment of these same rights." Thus, in the quest for "global harmony and the rule of law", the French revolution slogan must be readapted into "Liberty, equality and reciprocity".

\section{References}

Aristotle. 1988. Politics. Cambridge: Cambridge University Press.

Aristotle. 1999. Nicomachean ethics. Trans. T. Irwin, Indianapolis: Hackett.

Atienza, M. 1989a. Sociología jurídica y ciencia de la legislación. In El derecho y sus realidades. Investigación y enseñanza de la sociología juridica, ed. R. Bergalli. Barcelona: PPU.

Atienza, M. 1989b. Contribución a la teoría de la legislación. Doxa 6: 385.

Atienza, M. 1990. Para una teoría de la argumentación jurídica. Doxa 8: 39.

Atienza, M. 1997. Contribución a la teoría de la legislación. Madrid: Tecnos.

Austin, J. 1832. The province of jurisprudence determined and the uses of the study of jurisprudence, ed. J. Austin Indianapolis: Hackett.

Berlin, I. 1969. Four essays on liberty, ed. I. Berlin Oxford: Oxford University Press.

Bobbio, N. 1971. Le bon législateur. In Le raisonnment juridique/Legal reasoning/Die jurisdiche argumentation, ed. H. Hubien. Bruxelles: Établissements Émile Bruylant.

Bodenheimer, E. 1962. Jurisprudence. The philosophy and method of the law. Cambridge, MA: Harvard University Press.

Cicero, M.T. 1929. On the commonwealth. Trans. G.H. Sabine and S.B. Smith. Columbus: The Ohio State University Press.

Coke, E. 1607. Prohibitions del Roy. In The selected writings of Sir Edward Coke, vol. I, ed. S. Sheppard. Indianapolis: Liberty Fund.

Coke, E. 1608. Calvin's case, or the case of the postnati. In The selected writings of Sir Edward Coke, vol. I, ed. S. Sheppard. Indianapolis: Liberty Fund.

Confucius (2002), Analects. Trans. James Legge. Available at Project Gutenberg Etext, The Chinese Classics (Confucian Analects).

Constant, B. 1820. Collection complète des ouvrages. París: Béchet Libraire.

Dworkin, R. 1978. Taking rights seriously, 2nd ed. Cambridge, MA: Harvard University Press.

Dworkin, R. 1985. A matter of principle. Cambridge, MA: Harvard University Press.

Dworkin, R. 1986. Law's empire. Cambridge, MA: Harvard University Press.

Dworkin. Ronald. 1996. Freedom's law. The moral reading of the American constitution. Cambridge, MA: Harvard University Press.

Dworkin, Ronald. 2000. Sovereign virtue. The theory and practice of equality. Cambridge, MA: Harvard University Press.

Dworkin, R. 2006. Is democracy possible here? Principles for a new political debate. Princeton: Princeton University Press.

Dworkin, R. 2011. Justice for hedgehogs. Cambridge, MA: Harvard University Press. 
Flores, I.B. 2002. In the dark side of the conventionality thesis? In Studies in social, political and legal philosophy. Philosophy of law and of politics, ed. E. Villanueva. Amsterdam: Rodopi.

Flores, I.B. 2004. Assessing democracy and rule of law: Access to justice. In Proceedings of the 2/st IVR world congress, Lund (Sweden), 12-17 August, 2003, Part l: Justice, ed. A. Peczenik. Stuttgart: Franz Steiner Verlag.

Flores, I.B. 2005. The quest for legisprudence: Constitutionalism $v$. Legalism. In The theory and practice of legislation: Essays on legisprudence, ed. LJ. Wintgens. Aldershot: Ashgate.

Flores, I.B. 2007. Legisprudence: The forms and limits of legislation. Problema. Anuario de Filosofia y Teoria del Derecho 1: 247.

Flores, I.B. 2008. The living tree: Fixity and flexibility. A general theory of (judicial review in a) constitutional democracy? Problema. Anuario de Filosofia y Teoria del Derecho 2: 285.

Flores, I.B. 2009a. The living tree constitutionalism: Fixity and flexibility. Problema. Anuario de Filosofia y Teoria del Derecho 3: 37.

Flores, I.B. 2009b. Legisprudence: The role and rationality of legislators - vis-à-vis judges towards the realization of justice. Mexican Law Review 1(2): 91.

Flores, I.B. 2010. Ronald Dworkin's Justice for hedgehogs and partnership conception of democracy (with a comment to Jeremy Waldron's "A majority in the lifeboat"). Problema. Anuario de Filosofia y Teoria del Derecho 4: 65.

Fuller, L.L. 1958. Positivism and fidelity to law -A reply to professor Hart. Harvard Law Review 71:630.

Fuller, L.L. 1968. The anatomy of law. New York: Frederick A. Praeger.

Fuller, L.L. 1969. The morality of law, 2nd ed. New Haven: Yale University Press.

Fuller, L.L. 1999. The case of the speluncean explorers. Harvard Law Review 112: 1851.

Guinier, L. 1994. The tyranny of the majority. Fundamental fairness in representative democracy. New York: The Free Press.

Hamilton, A. 1985. Speech, June 18, 1787. In Selected writings and speeches of Alexander Hamilton, ed. M.J. Frisch. Washington, DC: American Enterprise Institute.

Hart, H.L.A. 1958. Positivism and the separation of law and morals. Harvard Law Review 71:593.

Hart, H.L.A. 1961. The concept of law. Oxford: Oxford University Press.

Hart, H.L.A. 1994. The concept of law, 2nd ed. Oxford: Oxford University Press.

Hayek, F.A. 1960. The constitution of liberty. Chicago: The University of Chicago Press.

Holmes, O.W. 1917. Southem Pacific v. Jensen, 244 U.S. 205.

Kelsen, H. 1945. General theory of law and state. Cambridge, MA: Harvard University Press.

Kelsen, H. 1967. Pure theory of law, 2nd ed. Trans. M. Knight, Berkeley: University of California Press.

Kelsen, H. 2002. Introduction to the problems of legal theory. Trans. B. Litschewski-Paulson and S.L. Paulson. Oxford: Oxford University Press.

Lincoln, A. 1990. New birth of freedom. The Gettysburg address, November 19, 1863. In Lincoln on democracy, ed. M.M. Cuomo and H. Holzer. New York: Harper Collins.

MacCormick, N. 1999. Questioning sovereignty: Law, state and nation in the European commonwealth. Oxford: Oxford University Press.

MacCormick, N. 2007. Institutions of law. An essay in legal theory. Oxford: Oxford University Press.

Madison, J. 1961. No. 51. In The federalist papers, ed. C. Rossiter. New York: Mentor.

Mansfield, W.M. 1770. $R$ v. Wilkes, 4 Burr 2527 [98 ER 327],

Marshall, J. 1824. Osborn v. Bank of United States, 22 U.S. 738.

Mill, J.S. 1958. Considerations on representative government. Indianapolis: Liberal Arts Press.

Mill, J.S. 1989. On liberty. In On liberty and other writings, ed. S. Collini. Cambridge: Cambridge University Press.

Rawls, J. 1971. A theory of justice. Cambridge, MA: Harvard University Press.

Scalia, A. 1989. The rule of law as a law of rules. University of Chicago Law Review 56: 1187.

Sen, A. 1992. Inequality reexamined. Cambridge, MA: Harvard University Press. 
Tocqueville, A. 1969. Democracy in America. New York: Anchor Books.

Waldron, J. 2002. Large legislatures. In Legal and political philosophy. Philosophy of law and of politics, ed. E. Villanueva. Amsterdam: Rodopi.

Waldron, J. 2008. The concept and the rule of law. Georgia Law Review 43: 1.

Waluchow, W.J. 2007. A common law theory of judicial review. The living tree. Cambridge: Cambridge University Press. 